\title{
First record of Alophia drummondii (Iridaceae) for the Paraíba state and Caatinga vegetation, Brazilian northeastern
}

\begin{abstract}
Alophia drummondii (Graham) R. Foster (Iridaceae), species previously reported only from Pernambuco state in Cerrado vegetation is identified first time at Paraiba state in Caatinga vegetation, Brazil. The identification was based on literature reports, including the protologue of the basyonim. The present study includes description of species, its habitat and phenology data as well as current geographical distribution.
\end{abstract}

Keywords: Asparagales, caatinga vegetation, monocots, new record
Volume 2 Issue 5 - 2018

\author{
José Iranildo Miranda de Melo,' Ana Paula \\ Araújo, ${ }^{2}$ Fernanda Kalina da Silva Monteiro, ${ }^{3}$ \\ Marcio Gleisson Medeiros Gonçalves, ${ }^{4}$ \\ Débora Coelho Moura ${ }^{2}$ \\ 'Department of Biology, Center of Biological Sciences and \\ Health, State University of Paraiba-UEPB, Brazil \\ ${ }^{2}$ Department of Geography, Federal University of Campina \\ Grande-UFCG, Brazil \\ ${ }^{3}$ Department of Biology, Federal Rural University of \\ Pernambuco-UFRPE, Brazil \\ ${ }^{4}$ Petroleum Engineering Academic Unit, Center of Science and \\ Technology, Federal University of Campina Grande-UFCG, \\ Brazil
}

Correspondence: José Iranildo Miranda de Melo, Department of Biology, Center of Biological Sciences and Health, State University of Paraiba, Bairro Universitário, 58429-500, Campina Grande, Paraíba, Brazil, Email tournefort@gmail.com

Received: May 16, 2018 | Published: September 05, 2018

\section{Introduction}

Iridaceae Juss. is included in the order Asparagales ${ }^{1}$ and consist of 66 genera and about 2,030 species. Presenting cosmopolitan distribution within South America and South Africa being their main centers of diversity. ${ }^{2}$ In Brazil, the family is represented by 198 species in 22 genera, of which 111 species and five genera are endemic to the country, mainly in the phytogeographical domains of the Atlantic Forest, Cerrado and Pampa. ${ }^{3}$

Alophia drummondii a herbaceous, shrub in some of their genera, with subterranean stem, rhizome or bulb; corms or bulbs with fibrous or membranous cataphylls, brown to red or purple. Its leaves are unifacial, equitant, dystic or spiral, cylindrical or flat, linear to ensiform, plicated or not, parallel-invigorating, invaginating at the base. The scapes are cylindrical or flattened, papillose or carrying one too many bracts foliaceous in their extension. The inflorescences may be spikes or monochasial cymes, exceptionally solitary flowers, terminal or axillary, pedunculate or sessile. Flowers showy, ephemeral, trimerous, diclamideous; free or connate tepals, petalloid; stamens 3, opposed to external tepals, fillaments free or connate, sometimes adnate to the perianth; anthers linear, oblong or sagittal, rimose or rarely poricidal; ovary inferior, usually trilocular, rarely unilocular, pluriovulate, axillary or rarely parietal placentation; styles 3 , free or partially united, usually petalloid, apical or lateral stigmas. The fruits are loculicidal capsules carrying one to many seeds per locule. Seeds globose or pyramidal. ${ }^{4,5}$

Alophia belongs to the Trimezieae tribe and occurs predominantly in temperate regions of the Americas, ${ }^{2,6}$ being represented by five species $^{7}$ two of them recorded in Brazil: A. drummondii (Graham)
R. Foster and A. medusae (Baker) Goldblatt, both associated to the phytogeographical domain of the Cerrado. ${ }^{3}$ This genus differs from the others of this family by panduriform anthers, with marginal sporangia and broad connective and stigmatic branches curved, almost in circles. ${ }^{6}$

Considering that several species of Iridaceae are used for commercial purposes, there are still few studies focusing their native representatives, especially in the Brazilian northeast region. This work revealed the first record of the genus Alophia (Iridaceae) for the state of Paraíba, Northeast Brazil, through A. drummondii that is also being recorded for the first time in the phytogeographic domain of Caatinga.

\section{Material and methods}

The specimen was obtained from the municipality of Soledade (Figure 1), a semi-arid region in the state of Paraíba, northeastern Brazil. Soledade $\left(07^{\circ} 03^{\prime} 26^{\prime \prime} \mathrm{S}, 36^{\circ} 21^{\prime} 46^{\prime \prime} \mathrm{W}\right)$ has a maximum of 521 meters and is limited to the municipalities of Olivedos (North), Boa Vista and Gurjão (South), Juazeirinho (West) and Pocinhos (East). Soledade is located in the geoenvironmental unit of the Borborema Plateau, under the Alto Pajeú Terrain, in the region locally called "Cariri Velhos Range", which originated from geological processes occurred since the Tertiary period, ${ }^{8,9}$ being located in the intermediate region of the Campina Grande municipality.

It has a territorial extension of $560,042 \mathrm{~km}^{2}$, with a population estimated in 2017 of 14,987 inhabitants, having a demographic density of 24.53 inhabitants per $\mathrm{km}^{2} .^{10}$ Its predominant climate is BSh - hot and dry tropical climate ${ }^{11}$ presenting an average annual temperature of $25^{\circ} \mathrm{C}$ and relative humidity of approximately $65 \% .{ }^{12}$ 
The geological base of the municipality consists of outcropping of granitic and gneiss rocks with quartz intrusions, which undergo mechanical wear from physical weathering and due to the thermal amplitude, causes the contraction and expansion of the rock. ${ }^{13}$ The exploitation of the Granite-gneiss is used as ornamental rock, being destined to the external commerce of the municipality (Campina Grande and João Pessoa municipalities), aspect that threatens the local biodiversity. The predominant soils are: vertisols, and luvisols, but are also common soil eutrophics, low-developed, shallow or very shallow littoral neosoils and rock outcrops of the Granitoid Complex (Gneisses and Granites are the most common), in the form of large "lajedos" or disaggregated blocks. ${ }^{14-16}$

The municipality of Soledade is situated at the area of the Paraíba River basin, the Taperoá River sub-basin. The water courses show intermittent flow regime and the dendritic drainage pattern ${ }^{15}$ and the Caatinga is the vegetative type of the region, characterized by intertropical xeromorphic domain and classified as a complex formation.

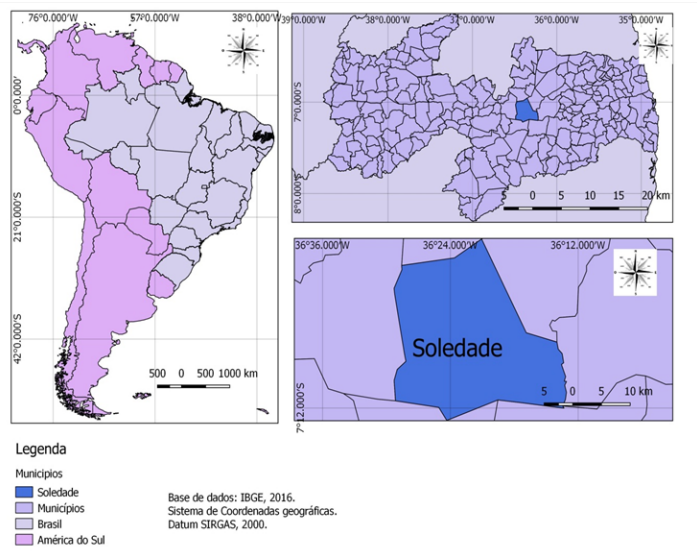

Figure I Location of the municipality of Soledade, Paraiba state, Brazilian northeastern.

\section{Results and discussion}

\section{Alophia drummondii (Graham) R. Foster, Contr. Gray Herb. 1 55:34. 1945. Figure 2A-C.}

Cypella drummondii Graham. Type: UNITED STATES OF AMERICA (?). Drummond s.n., s.d., apparently lost. Herbs, ca. $60 \mathrm{~cm}$ high; bulbs ca. $2.4 \mathrm{~cm}$ long. Leaves $1-3$ per plant, $25-40 \times 0.2-1 \mathrm{~cm}$, linear to narrow-lanceolate, membranaceous. Scape ca. $40 \mathrm{~cm}$ long, simple or branched, presenting 1-3 bracts, linear, the first bract ca. $35 \times 1.4 \mathrm{~cm}$, the others ca. $3.5 \times 0.4 \mathrm{~cm}$. 2-4 flowers, lax; peduncle ca. 9 $\mathrm{cm}$ long; spates ca. $5.4 \times 1.3 \mathrm{~cm}$. Flowers purple; obovate outer tepals, ca. $2.2 \times 1.3 \mathrm{~cm}$, apex rounded to truncate, brownish-brown grooves in the median-basal region; internal tepals ca. $1.5 \times 0.8 \mathrm{~cm}$, involutes, rounded apex, yellowish base with brown grooves, medium white whitish third with purple grooves; fillaments purple, ca. $2 \mathrm{~mm}$ long, attached to the base; anthers purple, ca. $8 \mathrm{~mm}$ long, oblong; ovary ca. $5 \mathrm{~cm}$ long, ovate; purple styles, ca. $6 \mathrm{~mm}$ long; bifid stigmas, filiform segments ca. $3 \mathrm{~mm}$ long. Capsule oblong, ca. $1.5 \times 0.8 \mathrm{~cm}$; seeds ca. $2.5 \times 2 \mathrm{~mm}$.

Examined specimen: Brazil. Paraíba: Soledade, Sítio Malhada Vermelha, 21-VII-2017, fl., A.P.A. Alves \& D. C. Moura 03 (ACAM ${ }^{1}$ ).

Distribution, habitat and reproductive phenology: A. drummondii

${ }^{1}$ Herbarium not indexed to Index Herbariorum. occurs from the United States of America and Mexico to South America ${ }^{17}$ In Brazil, it was previously recorded only for the state of Pernambuco, northeastern region, associated to the Cerrado vegetation. ${ }^{3}$ In Paraíba state, the species was found in an open area at the Caatinga vegetation flowering and fruiting in July.
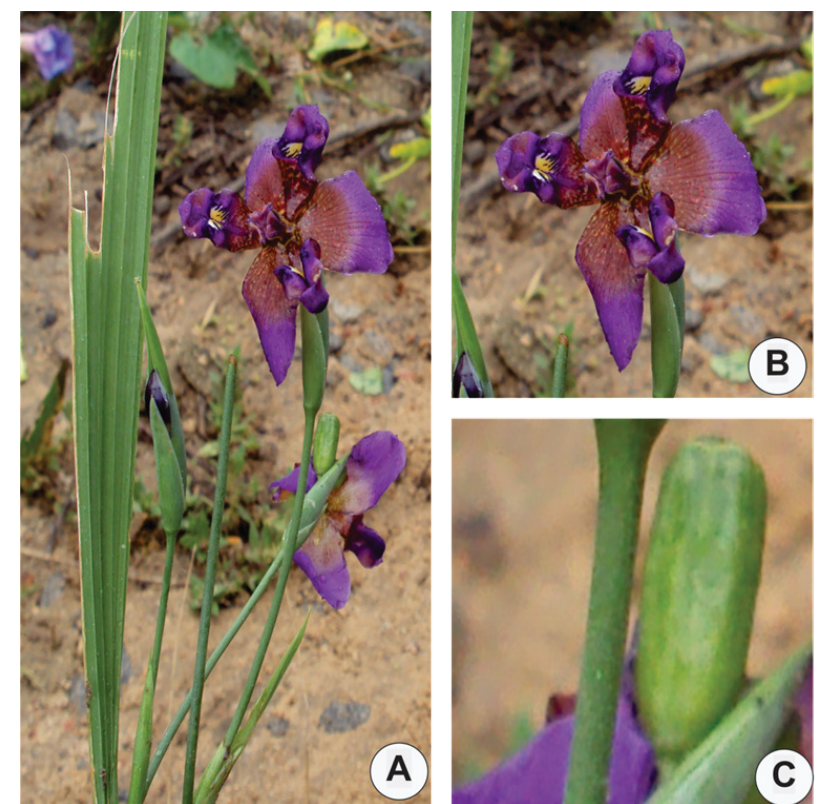

Figure 2 Alophia drummondii (Graham) R. Foster. (A) Habit. (B) Flower. (C) Fruit.

\section{Conclusion}

This new record reinforces the importance of the accomplishment of botanical collections especially in areas still scarcely known from the floristic and taxonomic point of view as is the case of the semi-arid region of the Brazilian Northeast (Caatinga vegetation), evidencing that the region called "Cariri" is an important center of floristic diversity.

\section{Acknowledgements}

The authors thank to Erimágna de Morais Rodrigues for preparing the map of the study area. JIM Melo thanks CNPq (Conselho Nacional de Desenvolvimento Científico e Tecnológico) for the Research Productivity Grant (PQ-2 Proc. n. 303867/2015-9).

\section{Conflict of interest}

There is no conflict of interest to declare regarding the publication of this paper.

\section{References}

1. APG IV. An update of the Angiosperm Phylogeny Group classification for the orders and families of flowering plants. Botanical Journal of the Linnean Society. 2016;181(1):1-20.

2. Goldblatt P, Rodriguez A, Powell MP, et al. Iridaceae Out of Australasia? Phylogeny, biogeography, and divergence time based on plastid DNA sequences. Systematic Botany. 2008;33(3):495-508.

3. http://floradobrasil.jbrj.gov.br/

4. https://www.kew.org/science/tropamerica/neotropikey/families/ Iridaceae.htm 
5. Oliveira PN, Giulietti AM, Oliveira RP. Flora da Bahia: Iridaceae. Sitientibus série Ciências Biológicas. 2016;16:1-38.

6. Goldblatt P, Howard TM. Notes on Alophia (Iridaceae) and a new species, A. veracruzana, from Vera Cruz, Mexico. Annals of the Missouri Botanical Garden. 1992;79(4):901-905.

7. http://www.theplantlist.org/

8. Santos CD, Moura ERT, Gonçalves JLG. Levantamento semidetalhado de solos da propriedade Sítio do Jardim: reclassificação aproximada dos solos e da aptidão agrícola. Areia: Universidade Federal da Paraíba; $2002.79 \mathrm{p}$

9. Correa ACB, Tavares BDAC, Monteiro KDA,et al. Megageomorfologia e morfoestrutura do Planalto da Borborema. Revista do Instituto Geológico. 2010;31(1-2):35-52.

10. https://censo2010.ibge.gov.br/

11. Köppen W. Das Geographische System der Klimatologie. Berlin; 1936. $44 \mathrm{p}$
12. http://www.inpe.br/dados_abertos/

13. Jatobá L, Lins RC. Introdução à Geomorfologia. Recife: Bagaço; 2008. $244 \mathrm{p}$.

14. Velloso AL, Sampaio EVSB, Pareyn FGC. Ecorregiões propostas para o Bioma Caatinga. Recife: Associação Plantas do Nordeste; Instituto de Conservação Ambiental \& The Nature Conservancy do Brasil; 2002. $75 \mathrm{p}$.

15. CPRM. Serviço Geológico do Brasil. Projeto cadastro de fontes de abastecimento por água subterrânea: diagnóstico do município de Boa Vista, estado da Paraíba. Recife: CPRM/Prodeem; 2005:19.

16. Empresa Brasileira de Pesquisa Agropecuária. Sistema Brasileiro de Classificação de Solos. Rio de Janeiro: Embrapa; 2006. 306 p.

17. http://www.tropicos.org 